\title{
Rents, Competition, and Corruption
}

\section{Citation}

Ades, Alberto, and Rafael Di Tella. 1999. "Rents, Competition, and Corruption." American Economic Review 89 (4): 982-93. https://doi.org/10.1257/aer.89.4.982.

\section{Permanent link}

http://nrs.harvard.edu/urn-3:HUL.InstRepos:41426667

\section{Terms of Use}

This article was downloaded from Harvard University's DASH repository, and is made available under the terms and conditions applicable to Other Posted Material, as set forth at http:// nrs.harvard.edu/urn-3:HUL.InstRepos:dash.current.terms-of-use\#LAA

\section{Share Your Story}

The Harvard community has made this article openly available.

Please share how this access benefits you. Submit a story.

Accessibility 


\title{
Rents, Competition, and Corruption
}

\author{
By Alberto Ades and Rafael Di Tella*
}

It is difficult to overstate the economic and social significance of corruption. Yet, the lack of reliable and systematic data has kept corruption out of the research agenda of empirical economists. This allowed speculation to include such basic issues as whether corruption is good or bad for growth or whether corruption is determined by economic or cultural forces. Recently, however, Paolo Mauro (1995) used cross-country subjective measures of corruption to show that corruption is negatively associated with private investment and growth. Our paper switches attention from the consequences of corruption to the causes of corruption.

Lawyers often argue that the way to reduce corruption is to reform the legal system so as to increase the punishment for malfeasance. ${ }^{1}$ Businessmen sometimes suggest that the problem of corruption lies in the low salaries bureaucrats receive relative to private-sector employees with comparable responsibilities. Accordingly, they argue to treat bureaucracies like private companies and raise the wages of public servants. $^{2}$ The economist's natural approach to corruption control is to appeal to the concept of competition as it is argued that bribes are harder to sustain where perfect competition prevails. Susan Rose-Ackerman (1978) first suggested that a way to reduce corruption was to introduce competition at the level of the official receiving bribes: when a bureaucrat dispenses a scarce benefit, the existence of competing officials to

\footnotetext{
* Ades: Goldman, Sachs \& Co., 85 Broad Street, New York, NY 10004; Di Tella: Graduate School of Business Administration, Harvard University, Soldiers Field, Boston, MA 02163. We are grateful to Mauro Alem, Christopher Bliss, Ed Glaeser, Igal Hendel, Robert MacCulloch, Paolo Mauro, Meg Meyer, Stephen Nickell, Andrew Oswald, Andrei Shleifer, and two referees for helpful suggestions. We thank Paolo Mauro for sharing the Business International data with us.

${ }^{1}$ See, for example, the comments of the Italian judge Antonio Di Pietro in The Financial Times, December 1, 1994.

${ }^{2}$ See, for example, Robert Klitgaard (1988) and Timothy Besley and John McLaren (1993).
}

reapply in case of being asked a bribe will bid down the equilibrium amount of corruption. ${ }^{3}$ In this paper we restrict attention to the other side of this problem, namely how does the industrial organization of the briber's market affect the equilibrium amount of corruption?

Theoretically the effect of competition on corruption is ambiguous. Less competition means firms enjoy higher rents, so that bureaucrats with control rights over them, such as tax inspectors or regulators, have higher incentives to engage in malfeasant behavior. The point is related to the more general idea that rents may foster slack. ${ }^{4}$ But this ignores the interaction of competition with the bureaucrat's incentive scheme. Higher rents also imply that the public would be keener to rewrite the bureaucrat's contract and to spend resources trying to control him. Since the equilibrium amount of bribes is determined by this contract, it is possible that less competition implies less corruption.

Examples of a positive connection between rents and corruption abound, however. Consider, for example, the case of Nigeria in the 1970 's. When compared to other, non-oilproducing countries in the region, like Togo, Nigeria provides what is almost a natural experiment for the hypothesis that rents cause corruption. After the oil shock, observers noted that Nigeria's oil income created extraordinary opportunities for corruption. An article in The Economist (August 4, 1984) went so far as to observe:

Oil and corruption go together. Nigeria's oil accounts for about $80 \%$ of government revenue. The official price of crude increased 17-fold in eight years from about \$2 a barrel in 1973-4 to \$34 by the end of 1981. Nigeria went on a construction and

\footnotetext{
${ }^{3}$ See also Andrei Shleifer and Robert Vishny (1993).

${ }^{4}$ This is an important idea in economics, going back at least to the work of John Hicks (1935), who pointed out that "the best of all monopoly profits is the quiet life."
} 
importing spree: Parties and party officials grew rich.

In this paper we explore the hypothesis that natural rents, as in the case of oil, and rents induced by the lack of product market competition foster corruption.

In Section I, we set up a model connecting rents to corruption. Section II describes our empirical strategy and the data sets used, while Sections III and IV present our empirical results. Section V concludes.

\section{A Simple Model}

There are two strands of literature that are relevant to the modeling of corruption. One is the literature on tax compliance and the other is the literature on compensation. We focus on the latter, but some of the themes of the literature on tax compliance, such as the appropriate levels of audits, should be seriously addressed in a more theoretical approach to corruption (see Jennifer Reinganum and Louis Wilde, 1985; Dilip Mookherjee and Ivan Png, 1989; inter alia).

Although most contributions to compensation theory were originally developed with private firms in mind (see Paul Milgrom and John Roberts [1992] for an exposition and the basic references), some work has been done on the extensions to cover the behavior of government agencies. It seems that one of the main differences is that bureaucracies are characterized by a multiplicity of objectives (see Jean Tirole [1994] for an excellent discussion). Indeed, state intervention is often justified because profit motives alone will not yield optimal allocation of resources. When the principal holds many objectives, piece rates and other state contingent contracts based on verifiable measures of performance are harder to write. One alternative, suggested by Gary Becker and George Stigler (1974), is to pay higher-thanmarket clearing wages and to periodically monitor the activities of the agent. This will induce the desired behavior if the agent is given highenough rents. We use an efficiency wage model of corruption to focus on only one aspect of this problem, namely the effect of rents on wage contracts and the equilibrium level of corruption.
When a firm under the influence of a bureaucrat enjoys rents, the value of his control right is high. Bureaucrats can reap some of this value by surrendering their control rights in exchange for bribes. ${ }^{5}$ Thus, an increase in rents, originated either on the discovery of a natural resource or in a decrease in competition, tends to increase corruption. There is, however, an opposing effect as the public may then become more concerned with controlling the bureaucrat, increasing the resources spent on corruption deterrence activities or by redefining the contract it has with the bureaucrat. This, in effect, makes the contract between the public and the bureaucrat a function of the level of rents. Since the equilibrium amount of bribes is determined by this contract, it is possible that less competition implies less corruption. The literature started by Oliver Hart (1983) on the relationship between managerial slack and product market competition makes a related point.

Assume that $n$ local firms and $N$ foreign firms sell their products in a certain market. Demand is linear with intercept $A$ and slope -1. Marginal cost of production for all firms is $k$, but foreign firms must pay a tariff $\tau$ and incur a transport cost equal to $d$ for each unit of output sold in the local market. Under Cournot competition, profits for the local firms is given by $\pi=[(A+N(\tau+d)-k) /(n+N+1)]^{2}$. The number of firms is large, but is fixed so there are positive profits in equilibrium. ${ }^{6}$

Assume there is a bureaucracy regulating the conduct of firms operating in the economy. Specifically assume it must assign one officer to each firm to extract profits $\pi(c)$, where $c$ represents our competition parameters (the tariff rate, the number of firms, or the level of transport costs). For simplicity assume that if regulation drives a firm out of the market there are infinite costs. Firms face idiosyncratic shocks. With probability $h$ a firm has high profits and

\footnotetext{
${ }^{5}$ Gunnar Myrdal (1968) notes the value to administrative officials of control rights to grant licenses or overlook violations of regulations as people "find such dispensations valuable and can afford to pay much for them. These controls therefore add greatly to the incentives for, and the rewards of graft and corruption."

${ }^{6}$ These assumptions are made without loss of generality. But see Christopher Bliss and Di Tella (1997) for a model of corruption where the number of firms is endogenous.
} 
with probability $1-h$ they are low (for simplicity assume them equal to zero in this state). The true level of profits is private information to the officer in charge of regulating each firm. In other words, there are two states of nature for each firm, $\pi$ and 0 . If low profits occur, the agent has no discretion and he reports it. If profits are high, he can claim that they were in fact low in exchange for a bribe, given by his share of the difference between real profits and reported profits, or $\Delta \pi=\pi-0$. For simplicity, assume the officer has full bargaining power so his share is 1 . The problem is to motivate the officer to reveal his information. To tackle this incentive problem in a straightforward way we assume the officer has limited liability and we do not allow state-contingent wages. The efficiency wage for the officer is that for which reporting the true level of profits when profits are high is incentive compatible. This is given by

$$
\text { (1) } w \geq(1-\theta)(w+\pi)+\theta\left(w^{0}-m\right)
$$

where $w^{0}$ is the opportunity wage, $m$ is the $e x$ post personal cost of being fired under corruption accusations, and $\theta$ is the probability of detection. ${ }^{7}$ Thus, an efficiency wage to deter corruption is given by

$$
w=w^{0}-m+\frac{1-\theta}{\theta} \pi
$$

A desirable feature of a model of corruption is that it allow for the existence of both honest and dishonest agents (see Brian Erard and Jonathan Feinstein, 1994). We incorporate this by assuming that the value of honesty is different across individuals, so that personal costs are distributed according to the distribution function $F\left(m<m^{*}\right)$. Because efficiency wages are not state contingent, they may be too expensive to implement and in some situations may give rise to a decision to allow corruption. The bureaucracy's problem is to choose the level of wages that maximizes the collection of profits net of wages. Higher-than-average wages are politi-

\footnotetext{
${ }^{7}$ For a formal model of efficiency wages applied to corruption, see Besley and McLaren (1993).
}

cally costly to the bureaucracy, a cost summarized by the function $g(\cdot)$. The bureaucracy's problem is to

$$
\underset{w}{\operatorname{Max}}(1-F(m))[h \pi]-g(w)
$$

such that $w$ is an efficiency wage. Note that, although raising the wage is costly to the bureaucracy, it increases the proportion of people reporting truthfully (being honest), given the circumstances. Thus, raising the bureaucrat's wage improves the probability that he does not behave corruptly [given by the population probability of honest employees, $1-F(m)$ ]. This, in turn, raises the probability of collecting high profits at rate $h$. The first-order condition is

$$
f(m) h \pi-g^{\prime}(w)=0
$$

with the second-order condition holding when $-f^{\prime}(m) h \pi-g^{\prime \prime}(w)<0$. Use of the implicit function theorem allows us to establish

$$
\text { (5) } \begin{aligned}
& \frac{\partial w}{\partial c} \\
= & -\frac{f^{\prime}(m) h \pi \frac{1-\theta}{\theta} \frac{\partial \pi}{\partial c}+f(m) h \frac{\partial \pi}{\partial c}}{-f^{\prime}(m) h \pi-g^{\prime \prime}(w)}
\end{aligned}
$$

When the numerator is negative, the expression is also negative indicating that the bureaucracy will lower wages as competition increases and the gain from discriminating between the two states falls.

Using equation (2) and the expression for profits under our Cournot assumptions, the frequency of corruption is given by

$$
\begin{aligned}
h F(m & \leq w^{0}-w \\
& \left.+\frac{1-\theta}{\theta} \frac{(A+N(\tau+d)-k)^{2}}{(n+N+1)^{2}}\right) .
\end{aligned}
$$

It is interesting to note that, in general, the effect on corruption of a higher level of competition is given by 


$$
h f(m)\left[-\frac{\partial w}{\partial c}+\frac{1-\theta}{\theta} \frac{\partial \pi}{\partial c}\right] .
$$

On the one hand, as competition increases, there is a tendency to lower wages as it becomes less attractive to induce honesty. On the other hand, the same wage deters more corruption as the gains to corrupt officials fall with competition. The result comes quite simply in this example, but is actually more general as seen in the literature on product market competition and managerial slack.

One attractive feature of the model is that it can be extended to the case where the government does not set bureaucratic wages with the objective of controlling corruption and also to the case where the government somehow does not realize that when it changes the competition parameters it is also changing the incentives for corrupt behavior. In both cases we have $\partial w /$ $\partial c=0$ in equation (7), and more competition (less rents) always decreases corruption.

\section{Empirical Strategy and Data}

It is difficult to present a comprehensive test of the model presented with the data available. Instead, our objective is to present some suggestive evidence on the general structure of corruption regressions. Equation (6) indicates three types of variables that may be relevant to the study of corruption: bureaucratic wages in country $i\left(w_{i}\right)$, variables that measure the amount of monitoring by civil society $\left(\theta_{i}\right)$, and variables that capture the level of profits of domestic firms $\left(\pi\left(c_{i}\right)\right)$. Under our simple Cournot specification, the latter would include the tariff rate, the transportation cost, and the number of firms both at home and abroad.

We were unable to obtain variables that measure the level of bureaucratic wages for our sample of countries. ${ }^{8}$ In order to capture the ability of civil society to judge government performance in each country we use variables that measure the general level of development in the

\footnotetext{
${ }^{8}$ But note that bureaucratic wages are less important under the extensions where $\partial w / \partial c=0$, particularly for our regressions controlling for fixed effects.
}

country, schooling (SCHOOL) and income per capita (GDP), and the Gastil index of political rights (POL). This last variable measures the lack of respect for political rights that facilitate the functioning of independent political parties. We assume that political competition allows the monitoring of the bureaucracy and helps to control corruption (CORR). Assuming linearity throughout for simplicity, we can write our basic estimating equation as

$$
\begin{aligned}
\operatorname{CORR}_{i}= & \beta_{0}+\beta_{1} \text { GDP }_{i}+\beta_{2} \text { SCHOOL }_{i} \\
& +\beta_{3} \text { POL }_{i}+\beta_{4} c_{i}+\varepsilon_{i} .
\end{aligned}
$$

The main focus of the empirical exercise is the sign and magnitude of $\beta_{4}$, the marginal effect of the variables capturing the level of rents and market structure on corruption. We proxy $c_{i}$ with the share of imports in GDP, the importance of fuels and mineral exports in the composition of total exports, and the distance to the world's major exporters. For our second sample, we also use the extent of market dominance by a limited number of enterprises, and the effectiveness of antitrust laws.

A major obstacle in the past for the economic analysis of corruption has been the lack of suitable data. An important feature of this study is its focus on subjective indices. This has both advantages and disadvantages. Some of the problems stem from the possibility that the persons generating the subjective reports do not share the same cardinal rankings or that the rankings are not uniform (i.e., that a change in corruption from 4 to 5 is different form a change in corruption from 6 to 7). Objective data, on the other hand, may be misleading. Mauro (1995) mentions the case of Italy's relative political stability in spite of more than 50 government changes since 1945. Also, hard data on corruption, like the number of reported fraud cases, may be inadequate as they depend on the legal classification system used in each country. More fundamentally, such data would be a mixed reflection of both the efficiency of the corruption deterrence system and of the prevalence of corruption. We avoid these problems by using subjective indices used commercially to measure corruption. There is also an argument of revealed preference in favor of using 
the same data that banks and multinationals use in making their investment decisions.

We use data on corruption from two different sources. The first set of corruption indices are published by Business International Corporation (1984) (BI), a private firm now incorporated into The Economist Intelligence Unit. BI sells these indices typically to banks, multinational companies, and other international investors. The indices are constructed from assessment reports filled in by BI's network of correspondents and analysts based in the countries covered. These reports undergo further checks at BI's regional level and corporate headquarters to ensure accuracy and consistency in the results. BI's correspondents must grade countries on a scale from 0 to 10 according to "The degree to which business transactions involve corruption or questionable payments," where a 0 implies the "best" grade, implying lack of corruption. The complete list of 52 countries included in this first data set is shown in Appendix B.

To complete this first data set, we also collected data on merchandise imports as a share of GDP from the World Bank's World Tables, data on fuels, minerals and metals exports from the World Development Report, data on total population and real per capita GDP from Robert Summers and Alan Heston (1991), and data on political rights from Raymond Gastil (1987). The Gastil index of political rights annually ranks countries in seven categories according to a checklist of political rights, from 0 to 7 where 7 is taken as not free. The checklist includes issues such as the existence of fair electoral laws, equal campaigning opportunities, fair polling, or if there is a significant opposition vote, among other political rights that are expected to influence the ability of the political process to exert an influence on the amount of monitoring over corrupt activities. The data on each country's land area were taken from the 1986 edition of the Food and Agricultural Organization (FAO) Production Yearbook, and are measured in 100,000 hectares. Our schooling data are for 1980 from Robert Barro and JongWha Lee (1994) and measures the average years of total schooling in the population over 25 years of age. In order to capture transportation costs we use a measure of "trade distance" from Barro and Lee (1994), which provides the log of the average distance in thousands of kilometers to capitals of the world's 20 major exporters, weighted by bilateral imports.

The second set of corruption indices comes from the 1990 and 1991 issues of the World Competitiveness Report (WCR), a publication by the EMF Foundation in Geneva (corresponding to 1989 and 1990). They are the product of surveys conducted amongst top and middle managers in the surveyed countries. Though the WCR has been used before as a source of data (e.g., see Bradford De Long and Lawrence Summers, 1991), its use as a source of corruption data is new. The size of the surveys was quite important: 1,800 in 1989 and 1,384 in 1990. The corruption question included in the survey asks on "the extent to which improper practices (such as bribing or corruption) prevail in the public sphere." The report contains also two additional indices that we use in our empirical work: (i) an index of Market Dominance, that measures "the extent to which dominance by a limited number of enterprises is detrimental to new business development," and (ii) an Antitrust Laws index, that measures "the effectiveness of anti-trust laws in checking noncompetitive practices." For all three indices, countries are graded in a 0 to 100 scale, with a 100 grade implying high corruption, high degree of market dominance by a few number of firms, and effective antitrust laws. The definition of the variables used is contained in Appendix A, while the complete list of 31 countries included in this second data set are shown in Appendix B.

To complete this second data set, we also collected data on real per capita GDP, on fuels, minerals and metals exports, and on the share of merchandise imports in GDP from the World Development Report. The data on political rights are from Gastil (1990, 1991), and the schooling data (which are for 1990) are from the 1993 issue of the Human Development Report.

Tables $1 \mathrm{~A}$ and $1 \mathrm{~B}$ show means, standard deviations, maxima, and minima for the main variables used in our regressions. It is interesting to note that the correlation coefficient between the two measures of corruption is quite high (0.84). As the time periods for the two measures do not overlap, this measure may be questionable. Taking the estimated model for the 1980's and obtaining a predicted value of corruption for the 
TABle 1A-Summary Statistics, 1980's SAmple ${ }^{a}$

\begin{tabular}{lccccc}
\hline \hline Variable & Observations & Mean & Standard deviation & Minimum & Maximum \\
\hline BI Corruption Index & 52 & 2.75 & 2.34 & 0 & 8.5 \\
Per Capita GDP (000) & 52 & 6.41 & 4.40 & 0.80 & 15.02 \\
Schooling & 52 & 5.93 & 2.85 & 1.68 & 12.14 \\
Lack of Political Rights & 52 & 2.82 & 1.88 & 0.08 & 6 \\
Share of Imports in GDP & 52 & 0.28 & 0.25 & 1 & 1.77 \\
Fuel and Mineral Exports & 52 & 24.12 & 26.64 & -3.52 & 99 \\
Trade Distance & 52 & 0.97 & 1.36 & 2.30 \\
\hline
\end{tabular}

${ }^{\text {a }}$ All variables are averages of their 1980 to 1983 observations.

Table 1B-Summary Statistics, 1990's SAMPLE ${ }^{a}$

\begin{tabular}{lcrrrr}
\hline \hline Variable & Observations & Mean & Standard deviation & Minimum & Maximum \\
\hline WCR Corruption Index & 31 & 4.06 & 1.53 & 1.36 & 6.82 \\
Per Capita GDP (000) & 31 & 12.01 & 5.53 & 1.01 & 21.69 \\
Schooling & 31 & 8.43 & 3.19 & 2.4 & 12.3 \\
Lack of Political Rights & 31 & 1.74 & 1.32 & 1 & 5.5 \\
Share of Imports in GDP & 31 & 0.35 & 0.36 & 0.06 & 1.75 \\
Fuel and Mineral Exports & 31 & 12.39 & 14.06 & -1.90 & 57 \\
Trade Distance & 31 & 1.14 & 0.89 & 40.91 & 2.26 \\
Market Dominance & 31 & 51.99 & 6.52 & 20.46 & 67.13 \\
Antitrust Law & 31 & 43.64 & 10.86 & 64.35 \\
\hline
\end{tabular}

${ }^{a}$ All variables are averages of their 1989 and 1990 observations.

1990 's (that is, using the values for the explanatory variables for the 1990's) we can see that the correlation coefficient between this predicted corruption and the actual value of corruption for the 1990's is $0.69(P>|t|=$ 0.00002 ). Taking the model from the 1990's and calculating the simple correlation coefficient between the predicted corruption for the 1980 's and the actual value of corruption during this period yields $0.77(P>|t|=2.25 e-$ 11).

\section{Evidence from the 1980's}

The first column in Table 2 shows our basic regression, which only includes our standard controls for the level of development (income per capita and Schooling) and the Gastil index of political rights. To allow for the possibility of heteroskedasticity, standard errors are Whitecorrected. Per Capita GDP has a negative effect on the BI Corruption Index (BICI). A onestandard-deviation increase in Per Capita GDP reduces the BICI by 1.57 points, approximately two-thirds of a standard deviation of this index. Schooling also has a negative effect on corrup- tion, though it is only significant at the 10percent level. The coefficient on our political competition variable is negative (though only significant at the 10-percent level), indicating that countries with low levels of political rights have lower corruption. ${ }^{9}$

Regression (2) adds three measures used to proxy for $c$, the extent to which domestic firms enjoy rents. The first is the Share of Imports in GDP. The coefficient on this variable is significant and indicates that a one-standard-deviation increase in the Share of Imports in GDP reduces the BICI by 0.47 points, or 20 percent of a standard deviation in the corruption index. The effect is economically significant: almost a third of the corruption gap between Italy and Austria can be explained by Italy's lower exposure to foreign

\footnotetext{
${ }^{9}$ Throughout this paper we fail to find beneficial and significant effects of political rights on corruption. If anything, lack of political rights seems to be associated with less corruption. It is worth noting that the raw data present a group of countries with very low corruption and political rights such as Iraq, Hong Kong, and Singapore. The result deserves closer scrutiny as it still holds using robust regression techniques.
} 
TABLE 2-CORRUPTION REgRESSION FOR THE 1980's SAMPLE ${ }^{\mathrm{a}}$

\begin{tabular}{|c|c|c|c|c|}
\hline \multirow[b]{2}{*}{ Dependent variable } & \multicolumn{3}{|c|}{ Average BI Corruption Index (1980-1983) } & \multirow{2}{*}{$\begin{array}{c}\begin{array}{c}\text { BI Corruption } \\
\text { Index }(1980-1983)\end{array} \\
(4) \\
\text { Fixed effects }\end{array}$} \\
\hline & $\begin{array}{c}\text { (1) } \\
\text { OLS }\end{array}$ & $\begin{array}{c}(2) \\
\text { OLS }\end{array}$ & $\begin{array}{c}\text { (3) } \\
\text { TSLS }\end{array}$ & \\
\hline Intercept & $\begin{array}{c}7.413 \\
(0.949)\end{array}$ & $\begin{array}{c}7.281 \\
(0.966)\end{array}$ & $\begin{array}{c}7.408 \\
(0.944)\end{array}$ & \\
\hline Real per Capita GDP & $\begin{array}{c}-0.357 \\
(0.107)\end{array}$ & $\begin{array}{c}-0.381 \\
(0.090)\end{array}$ & $\begin{array}{c}-0.376 \\
(0.093)\end{array}$ & $\begin{array}{c}-0.489 \\
(0.243)\end{array}$ \\
\hline Schooling & $\begin{array}{c}-0.247 \\
(0.136)\end{array}$ & $\begin{array}{c}-0.190 \\
(0.125)\end{array}$ & $\begin{array}{c}-0.199 \\
(0.129)\end{array}$ & \\
\hline Lack of Political Rights & $\begin{array}{c}-0.321 \\
(0.178)\end{array}$ & $\begin{array}{c}-0.406 \\
(0.160)\end{array}$ & $\begin{array}{c}-0.401 \\
(0.146)\end{array}$ & $\begin{array}{c}0.092 \\
(0.114)\end{array}$ \\
\hline Share of Imports in GDP & & $\begin{array}{c}-1.871 \\
(0.669)\end{array}$ & $\begin{array}{c}-2.229 \\
(1.073)\end{array}$ & $\begin{array}{c}-2.405 \\
(1.366)\end{array}$ \\
\hline Fuel and Mineral Exports & & $\begin{array}{c}0.014 \\
(0.008)\end{array}$ & $\begin{array}{c}0.014 \\
(0.007)\end{array}$ & $\begin{array}{c}0.003 \\
(0.009)\end{array}$ \\
\hline Trade Distance & & $\begin{array}{c}0.375 \\
(0.131)\end{array}$ & $\begin{array}{c}0.370 \\
(0.145)\end{array}$ & \\
\hline Number of observations & 52 & 52 & 52 & 186 \\
\hline Adjusted $R^{2}$ & 0.58 & 0.68 & 0.68 & 0.90 \\
\hline
\end{tabular}

${ }^{\text {a }}$ Standard errors are in parentheses. In regression (3) we treat the Share of Imports in GDP as endogenous. The instruments used are the $\log$ of population and the log of land area. In regression (4) we control for country and time fixed effects.

imports. Our interpretation of this result is that competition from foreign firms reduces the rents enjoyed by domestic firms, and this reduces the rewards from corruption. It is also consistent with corruption being associated with the rents generated by the restrictiveness of the trade regime, as suggested by Krueger (1974). The second measure is the proportion of total exports accounted by fuels, minerals, and metals. It provides a measure related to exogenously created rents for domestic firms. It is positive and significant at the 6-percent level. A one-standard-deviation increase in the Fuel and Mineral Exports variable is associated with an increase in corruption of 0.37 points, or 16 percent of a standard deviation in the corruption index. The third and last measure of rents is Trade Distance. The rationale for using this variable is that domestic firms in markets that are "sheltered" from foreign competition by a long physical distance to the world's leading exporters have a cost advantage (lower transport costs) to serve the domestic market. The coefficient is positive and significant, indicating that countries that are protected by higher transport costs have higher corruption. A one-standard-deviation increase in Trade Distance increases corruption by 0.51 points, or 22 percent of a standard deviation in the corruption index.
The specification we use in this paper may sound unorthodox to readers familiar with the rent-seeking literature. ${ }^{10}$ The emphasis there is on bureaucrats that determine market structure in exchange for bribes. Although this should not affect the results on Fuels and Mineral Exports and Trade Distance, it implies that there is the potential for a simultaneity bias in the coefficient on the Share of Imports in GDP variable. Attractive as this hypothesis sounds, we should emphasize that the nature of the corruption data we use is extremely unlikely to capture this type of corruption. For example, this hypothesis would require that the bureaucrat soliciting the bribe has indeed the power to affect trade barriers directly. Alternatively, it would require the collusion between those with the power to affect trade barriers (like legislators or officials in the Trade Ministry), and those able to extract bribes (like regulators or local tax inspectors). Competition-reducing corruption seems more likely to involve high-ranked officials-maybe even ministers-which would not be observed

\footnotetext{
${ }^{10}$ The classic papers on rent seeking are by Gordon Tullock (1967), Anne O. Krueger (1974), and Jagdish Bhagwati (1982).
} 
by the BI correspondents. To assess this possibility empirically, however, we use two-stage least-squares (TSLS) techniques. ${ }^{11}$

Regression (3) in Table 2 treats the Share of Imports in GDP as endogenous and uses the log of population and the log of land area as instruments. Our identifying assumptions are that these variables only affect corruption through their effect on the Share of Imports in GDP. ${ }^{12}$ We then tested these assumptions using Hausman tests of the overidentifying restrictions for the system of equations and could not reject the restrictions at conventional levels. ${ }^{13}$ The coefficient on the Share of Imports in GDP is again negative and significant, and it is almost 19percent larger than the OLS estimate.

Another potential source of concern is the incidence of omitted variables. Our results may indeed reflect the influence of variables not included in our regressions that affect both corruption and market structure. A particularly important class of candidate variables are time invariant, such as institutional arrangements, constitutional tradition, or social mobility. Regression (4) deals with this possibility by controlling for country and time fixed effects in panel regressions. ${ }^{14}$ The coefficient on Schooling and Trade Distance do not show, as there is

\footnotetext{
${ }^{11}$ Other variables in regression (2), such as Schooling or income, may also be endogenous.

${ }^{12}$ The use of land area as an instrument can be justified theoretically by its relation to transport costs. In countries where domestic transport costs are high due to large land area, domestic producers can locate their manufacturing plants close to the markets they supply and enjoy a cost advantage over foreign producers, who must pay the cost of transport from the border to the market. The use of population size as an instrument is justified as a proxy for the realization of increasing returns through market size. There is a vast literature on the subject, reviewed in Dwight $\mathrm{H}$. Perkins and Moshe Syrquin (1989).

${ }^{13}$ The $p$-values for the test of the overidentifying restrictions are obtained by running the residuals from regression (3) on all of the predetermined variables in the model. The uncentered $R^{2}$ multiplied by the number of observations is distributed as a $\chi^{2}$ with $j$ degrees of freedom, where $j$ is the difference between the number of exogenous variables excluded from the model minus the number of endogenous variables included in the model. The corresponding $p$-value is 0.95 . Though there is an issue with the low power of such tests, we are far from being able to reject our identifying assumptions at conventional levels.

${ }^{14}$ The number of observations falls to 186 as there are missing observations. Running a balanced panel does not affect the results.
}

no variation in these variables across time. The coefficient on the Share of Imports in GDP is negative and significant at the 8-percent level, and its size is 28-percent larger than that in regression (2), indicating that countries where competition from foreign imports increases experience a reduction in the level of corruption. The coefficient on Real per Capita GDP is significant and negative, so the evidence is also consistent with corruption increasing during an economic downturn. The effect of Fuel and Mineral Exports is positive but not significant.

\section{Evidence from the 1990's}

In this section, we present evidence obtained using data on corruption from the World Competitiveness Report (WCR). The sample employed here is smaller both in its cross-section and time-series dimensions than the one constructed for the 1980's. However, some of the variables available from the WCR offer a more direct measure of competition. Originally the WCR corruption data is measured on a scale from 0 to 100 (mean 40.6). We normalize the data so that it is also on a scale from 0 to 10 and we have the dependent variable on a common scale for both the 1980's and 1990's.

Regression (5) in Table 3 shows our basic regression for the WCR data. Per Capita GDP and Schooling both have a negative effect on corruption, though not significant at conventional levels. The Gastil index of political rights is also negatively correlated with the WCR index, indicating that, in our sample, countries with low political rights have low corruption. The size of the coefficients is not out of line with those in regression (1).

In regression (6) we include the same three measures of $c$ that were available for the 1980's. The coefficient on the Share of Imports in GDP is again negative and significant. A one-standarddeviation increase in this variable leads to a reduction in the WCR corruption index of 0.74 points, over 48 percent of a standard deviation of this index. The coefficient on Fuels and Mineral Exports is negative and insignificant. The coefficient on Trade Distance is positive, though only significant at the 12-percent level. A one-standarddeviation increase in Trade Distance increases the WCR corruption index by 15 percent of a standard deviation. 
TABLE 3 - CORRUPTION REgRessions FOR THE 1990's SAMPLE ${ }^{a}$

\begin{tabular}{|c|c|c|c|c|}
\hline \multirow[b]{2}{*}{ Dependent variable } & \multicolumn{3}{|c|}{ Average WCR Corruption Index (1989-1990) } & \multirow{2}{*}{$\begin{array}{l}\text { WCR Corruption } \\
\text { Index }(1989-1990) \\
(8)\end{array}$} \\
\hline & $(5)$ & (6) & (7) & \\
\hline Intercept & $\begin{array}{c}8.086 \\
(0.896)\end{array}$ & $\begin{array}{c}7.843 \\
(0.917)\end{array}$ & $\begin{array}{c}7.851 \\
(0.913)\end{array}$ & \\
\hline Real per Capita GDP & $\begin{array}{c}-0.169 \\
(0.087)\end{array}$ & $\begin{array}{c}-0.064 \\
(0.066)\end{array}$ & $\begin{array}{c}-0.062 \\
(0.068)\end{array}$ & $\begin{array}{c}0.784 \\
(0.301)\end{array}$ \\
\hline Schooling & $\begin{array}{c}-0.160 \\
(0.170)\end{array}$ & $\begin{array}{c}-0.269 \\
(0.139)\end{array}$ & $\begin{array}{c}-0.272 \\
(0.128)\end{array}$ & \\
\hline Lack of Political Rights & $\begin{array}{c}-0.372 \\
(0.187)\end{array}$ & $\begin{array}{c}-0.175 \\
(0.130)\end{array}$ & $\begin{array}{c}-0.170 \\
(0.229)\end{array}$ & $\begin{array}{c}-0.068 \\
(0.562)\end{array}$ \\
\hline Share of Imports in GDP & & $\begin{array}{c}-2.051 \\
(0.621)\end{array}$ & $\begin{array}{r}-2.082 \\
(0.772)\end{array}$ & $\begin{array}{c}-12.73 \\
(4.279)\end{array}$ \\
\hline Fuel and Mineral Exports & & $\begin{array}{c}-0.002 \\
(0.007)\end{array}$ & $\begin{array}{c}-0.002 \\
(0.014)\end{array}$ & $\begin{array}{c}0.119 \\
(0.187)\end{array}$ \\
\hline Trade Distance & & $\begin{array}{c}0.266 \\
(0.164)\end{array}$ & $\begin{array}{c}0.263 \\
(0.236)\end{array}$ & \\
\hline Number of observations & 31 & 31 & 31 & 62 \\
\hline Adjusted $R^{2}$ & 0.54 & 0.69 & 0.69 & 0.70 \\
\hline
\end{tabular}

${ }^{a}$ Standard errors are in parentheses. In regression (7) we treat the Share of Imports in GDP as endogenous. The instruments are the $\log$ of land area and the log of population. In regression (8) we control for country and time fixed effects.

Again, to assess empirically the possibilities of a simultaneity bias and the existence of omitted variables, we use TSLS techniques and we control for fixed effects. In regression (7) in Table 3, we use TSLS techniques to identify exogenous effects on the Share of Imports in GDP using the log of population and the log of land area as instruments. The coefficients are very similar to the OLS estimates. Regression (8) analyzes the relationship between competition and corruption free of the influence of time-invariant omitted variables by reproducing regression (6) in the panel and controlling for country and time fixed effects. In regression (8), the coefficient on the Share of Imports in GDP is negative and significant, though it is considerably larger than the OLS estimate. This could be due to the fact that the panel is shorter on both groups of data than that presented in Table 2 , and that many of the variables used move slowly over time. The results, however, are still consistent with the idea that more competition reduces the rents available to firms and thus reduces corruption. The interpretation that corruption increases during a downturn that we proposed in regression (4) is more difficult to make in this regression as the coefficient on Real per Capita GDP is now positive and significant.
In Table 4 we present the results obtained using other, perhaps more direct, measures of the degree of competition in the economy. In regression (9), we include the Market Dominance and Antitrust Law variables from the WCR. The coefficient on Market Dominance is positive, though significant only at the 15 percent level. Thus, there is only weak evidence in an OLS regression that countries with markets dominated by a few firms have higher corruption. A one-standard-deviation increase in Market Dominance increases corruption by 0.29 points, almost 19 percent of a standard deviation in the WCR corruption index. The coefficient on the Antitrust Law variable is negative and significant at the 6-percent level. This suggests that countries where antitrust laws are effective in checking noncompetitive practices have lower rents and lower corruption. The result, however, is also consistent with other interpretations: the Antitrust Law variable may be providing a general measure of the development of the legal system so we are capturing the fact that laws are effective in controlling corruption. A one-standard-deviation increase in the Antitrust Law variable reduces corruption by 0.53 points, almost 35 percent of this index.

In regression (10) we include all the variables that may capture the extent to which domestic 
TABLE 4-CORRUPTION REgRessions for THE 1990's SAMPLE ${ }^{a}$

\begin{tabular}{|c|c|c|c|c|c|}
\hline \multirow[b]{2}{*}{ Dependent variable } & \multicolumn{3}{|c|}{$\begin{array}{l}\text { Average WCR Corruption Index } \\
(1989-1990)\end{array}$} & \multicolumn{2}{|c|}{$\begin{array}{l}\text { WCR Corruption Index } \\
(1989-1990)\end{array}$} \\
\hline & $\begin{array}{l}(9) \\
\text { OLS }\end{array}$ & $\begin{array}{l}(10) \\
\text { OLS }\end{array}$ & $\begin{array}{l}(11) \\
\text { TSLS }\end{array}$ & $\begin{array}{c}(12) \\
\text { Fixed effects }\end{array}$ & $\begin{array}{c}(13) \\
\text { Fixed effects }\end{array}$ \\
\hline Intercept & $\begin{array}{c}6.961 \\
(1.921)\end{array}$ & $\begin{array}{l}9.503 \\
(2.028)\end{array}$ & $\begin{array}{l}10.28 \\
(2.244)\end{array}$ & & \\
\hline Real per Capita GDP & $\begin{array}{c}-0.131 \\
(0.071)\end{array}$ & $\begin{array}{r}-0.072 \\
(0.058)\end{array}$ & $\begin{array}{c}-0.042 \\
(0.064)\end{array}$ & $\begin{array}{c}0.029 \\
(0.413)\end{array}$ & $\begin{array}{c}0.083 \\
(0.384)\end{array}$ \\
\hline Schooling & $\begin{array}{c}-0.079 \\
(0.136)\end{array}$ & $\begin{array}{c}-0.159 \\
(0.107)\end{array}$ & $\begin{array}{c}-0.212 \\
(0.131)\end{array}$ & & \\
\hline Lack of Political Rights & $\begin{array}{c}-0.462 \\
(0.151)\end{array}$ & $\begin{array}{c}-0.302 \\
(0.114)\end{array}$ & $\begin{array}{c}-0.183 \\
(0.225)\end{array}$ & $\begin{array}{c}-0.426 \\
(0.328)\end{array}$ & $\begin{array}{c}-0.385 \\
(0.299)\end{array}$ \\
\hline Share of Imports in GDP & & $\begin{array}{l}-1.855 \\
(0.527)\end{array}$ & $\begin{array}{c}-2.562 \\
(0.768)\end{array}$ & & $\begin{array}{c}-8.675 \\
(5.187)\end{array}$ \\
\hline Fuel and Mineral Exports & & $\begin{array}{c}0.003 \\
(0.007)\end{array}$ & $\begin{array}{c}-0.001 \\
(0.014)\end{array}$ & & $\begin{array}{c}0.051 \\
(0.152)\end{array}$ \\
\hline Trade Distance & & $\begin{array}{c}0.308 \\
(0.126)\end{array}$ & $\begin{array}{c}0.263 \\
(0.226)\end{array}$ & & \\
\hline Market Dominance & $\begin{array}{c}0.044 \\
(0.030)\end{array}$ & $\begin{array}{c}-0.005 \\
(0.031)\end{array}$ & $\begin{array}{l}-0.018 \\
(0.033)\end{array}$ & $\begin{array}{c}0.086 \\
(0.026)\end{array}$ & $\begin{array}{c}0.080 \\
(0.024)\end{array}$ \\
\hline Antitrust Law & $\begin{array}{r}-0.049 \\
(0.025)\end{array}$ & $\begin{array}{r}-0.050 \\
(0.013)\end{array}$ & $\begin{array}{r}-0.048 \\
(0.022)\end{array}$ & $\begin{array}{c}-0.077 \\
(0.023)\end{array}$ & $\begin{array}{c}-0.064 \\
(0.028)\end{array}$ \\
\hline Number of observations & 31 & 31 & 31 & 62 & 62 \\
\hline Adjusted $R^{2}$ & 0.62 & 0.73 & 0.71 & 0.75 & 0.75 \\
\hline
\end{tabular}

${ }^{\text {a }}$ Standard errors are in parentheses. In regression (11) we treat the Share of Imports in GDP as endogenous. The instruments are the $\log$ of land area and the log of population. In regressions (12) and (13) we control for country and time fixed effects.

firms have rents. The results remain encouraging for the hypothesis that rents foster corruption. The coefficients on the Share of Imports in GDP, Trade Distance, and Antitrust Laws are significant and have the correct sign. The one on Fuel and Mineral Exports is positive, though it is not significant at conventional levels. The coefficient on Market Dominance is insignificant and has the wrong sign. In regression (11), we treat the Share of Imports in GDP as endogenous under this general specification using TSLS techniques. The instruments are the log of land area and the log of population. The coefficient is still negative and significant, though somewhat larger than the OLS estimate and the TSLS estimate under the previous specification [regression (7)]. Regressions (12) and (13) present panel regressions controlling for year and country fixed effects under both specifications. In both regressions the coefficients on Market Dominance and Antitrust Law have the correct sign, are larger than the OLS estimate, and are comfortably significant. In contrast with regression (8), the coefficient on Real per Cap- ita GDP is insignificant (but still positive), so the cyclical character of corruption remains an open question. In regression (13), under the most general specification, the coefficient on the Share of Imports in GDP is still negative, though it is only significant at the 11-percent level.

\section{Conclusion}

This paper presents what we believe is the first empirical study of the causes of corruption across countries. We examine the hypothesis that the level of rents in general, and market structure in particular, determine the level of corruption in the economy. Theoretically the effect of rents, of which competition-induced rents is one example, on corruption is ambiguous. Less competition means bureaucrats can extract more rents from the firms they control, but it also means that it is more valuable for the public to avoid corruption and, thus, is more likely to try to control the bureaucrat.

Our empirical results are one sided however. 
Both in our basic cross-section analysis and controlling for country and time fixed effects we find that, other things equal, countries where firms enjoy higher rents tend to have higher corruption levels. Using data on corruption from two different sources, we find that corruption is higher in countries where domestic firms are sheltered from foreign competition by natural or policy induced barriers to trade, with economies dominated by a few number of firms, or where antitrust regulations are not effective in preventing anticompetitive practices. The size of the effect is rather large: almost a third of the corruption gap between Italy and Austria can be explained by Italy's lower exposure to foreign competition.

These results suggest that policies aimed at making markets more competitive could play a role in controlling corruption. ${ }^{15}$

\section{Appendix A: Definition of Variables}

BI Corruption Index: The degree to which business transactions involve corruption or questionable payments. Assessed from 0 to 10 by Business International's network of correspondents, with 10 meaning maximum corruption.

GDP: Real per capita GDP, in thousands of U.S.\$.

Lack of Political Rights: The Gastil index of political rights. Measured in decreasing order from 0 to 7 according to a checklist of political rights ( 7 is not free).

Schooling: Average years of total schooling in the population over 25 years of age.

Fuel and Mineral Exports: Percentage share of merchandise exports accounted by fuels, minerals, and metals exports.

Trade Distance: Log of Barro-Lee measure average distance in thousands of kilometers to the capitals of the world's 20 largest exporters, weighted by values of bilateral exports.

WCR Corruption Index: The extent to which improper practices (such as bribing or corruption) prevail in the public sphere, measured from 0 to 10 (10 is maximum corruption). A survey of top and middle managers in each

\footnotetext{
${ }^{15}$ For some policy implications, see Ades and Di Tella (1997).
}

country conducted by the World Competitiveness Report.

Market Dominance: The extent to which market dominance by a limited number of enterprises is detrimental to new business development, measured from 0 to 100 (100 is maximum market dominance). A survey of top and middle managers in each country conducted by the World Competitiveness Report.

Antitrust Laws: The effectiveness of antitrust laws in checking noncompetitive practices, measured from 0 to 100 (100 is completely effective antitrust laws). A survey of top and middle managers in each country conducted by the World Competitiveness Report.

\section{APPENDix B: List of Countries}

\section{BI 1980's Sample of 52 Countries}

Algeria, Cameroon, Kenya, South Africa, Bangladesh, India, Israel, Japan, Jordan, Korea, Malaysia, Pakistan, Philippines, Singapore, Sri Lanka, Thailand, Austria, Belgium, Denmark, Finland, France, Germany, Greece, Ireland, Italy, Netherlands, Norway, Portugal, Spain, Sweden, Switzerland, Turkey, United Kingdom, Canada, Dominican Republic, Jamaica, Mexico, Nicaragua, Panama, Trinidad and Tobago, United States, Argentina, Brazil, Chile, Colombia, Ecuador, Peru, Uruguay, Venezuela, Australia, New Zealand, Indonesia.

\section{WCR 1990's Sample of 31 Countries}

Hong Kong, India, Japan, Korea, Malaysia, Singapore, Thailand, Austria, Belgium, Denmark, Finland, France, Germany, Greece, Ireland, Italy, The Netherlands, Norway, Portugal, Spain, Sweden, Switzerland, Turkey, United Kingdom, Canada, Mexico, United States, Brazil, Australia, New Zealand, Indonesia.

\section{REFERENCES}

Ades, Alberto and Di Tella, Rafael. "National Champions and Corruption: Some Unpleasant Interventionist Arithmetic." Economic Journal, July 1997, 107(443), pp. 1023-42.

Barro, Robert and Lee, Jong-Wha. "Data Set for a Panel of 138 Countries." Mimeo, Harvard University, 1994. 
Becker, Gary and Stigler, George. "Law Enforcement, Malfeasance and the Compensation of Enforcers." Journal of Legal Studies, January 1974, 3 (1), pp. 1-19.

Besley, Timothy and McLaren, John. "Taxes and Bribery: The Role of Wage Incentives." Economic Journal, January 1993, 103 (416), pp. 119-41.

Bhagwati, Jagdish. "Directly Unproductive ProfitSeeking (DUP) Activities." Journal of Political Economy, October 1982, 90 (5), pp. 988-1002.

Bliss, Christopher and Di Tella, Rafael. "Does Competition Kill Corruption?" Journal of Political Economy, October 1997, 105 (5), pp. 1001-23.

Business International Corporation. Introduction to the country assessment service. New York: Business International Corporation, 1984.

De Long, Bradford and Summers, Lawrence. "Equipment Investment and Economic Growth." Quarterly Journal of Economics, May 1991, 106 (2), pp. 445-502.

Di Pietro, Antonio. "Ruling Sets Back Italian Graft Inquiry." Financial Times, December 1, 1994, p. 3.

Economist, The. "Nigeria: You're in the Army Now, or Nearly So." August 4, 1984, pp. 33-34.

Erard, Brian and Feinstein, Jonathan. "Honesty and Evasion in the Tax Compliance Game." Rand Journal of Economics, Spring 1994, 25 (1), pp. 1-19.

Food and Agricultural Organization (FAO). Production yearbook, FAO Statistics Series. Rome: FAO, 1986.

Gastil, Raymond. Freedom in the world. Westport, CT: Greenwood Press, various years.

Hart, Oliver. "The Market as an Incentive Scheme." Bell Journal of Economics, Autumn 1983, 14 (2), pp. 366-82.

Hicks, John. "Annual Survey of Economic Theory: The Theory of Monopoly." Economet rica, January 1935, 3 (3), pp. 1-20.

Human Development Report, United Nations Development Programme. New York: Oxford University Press, 1993.

Klitgaard, Robert. Controlling corruption. Berkeley, CA: University of California Press, 1988.
Krueger, Anne O. "The Political Economy of the Rent-Seeking Society." American Economic Review, June 1974, 64 (3), pp. 291303.

Mauro, Paolo. "Corruption and Growth." Quarterly Journal of Economics, August 1995, 110 (3), pp. 681-712.

Milgrom, Paul and Roberts, John. Economics organization and management. Englewood Cliffs, NJ: Prentice Hall International Editions, 1992.

Mookherjee, Dilip and Png, Ivan. "Optimal Auditing, Insurance, and Redistribution." Quarterly Journal of Economics, May 1989, 104 (2), pp. 399-415.

Myrdal, Gunnar. Asian drama: An inquiry into the poverty of nations, Vol. II. New York: Pantheon, 1968.

Perkins, Dwight H. and Syrquin, Moshe. "Large Countries: The Influence of Size," in Hollis Chenery and T. N. Srinivasan, eds., Handbook of development economics, Vol. 2. New York: Elsevier Science Publishers, 1989, pp. 1691-751.

Reinganum, Jennifer and Wilde, Louis. "Income Tax Compliance in a Principal-Agent Framework." Journal of Public Economics, February $1985,26(1)$, pp. 1-18.

Rose-Ackerman, Susan. Corruption: A study of political economy. New York: Academic Press, 1978.

Shleifer, Andrei and Vishny, Robert. "Corruption." Quarterly Journal of Economics, August 1993, 108 (3), pp. 599-617.

Summers, Robert and Heston, Alan. "The Penn World Table (Mark 5): An Expanded Set of International Comparisons, 1950-1988." Quarterly Journal of Economics, May 1991, 106 (2), pp. 327-68.

Tirole, Jean. "The Internal Organization of Government." Oxford Economic Papers, January 1994, 46 (1), pp. 1-29.

Tullock, Gordon. "The Welfare Costs of Tariffs, Monopolies, and Theft." Western Economic Journal, June 1967, 5 (2), pp. 224-32.

World Competitiveness Report. Geneva, Switzerland: EMF Foundation, various years.

World Development Report, World Bank. New York: Oxford University Press, various years. 